\title{
FINANČNÍ STABILITA ČR V PODMÍNKÁCH SOUČASNÉHO EKONOMICKÉHO SYSTÉMU ${ }^{1}$
}

\author{
Michaela Otýpková
}

\section{Klíčová slova:}

Finanční stabilita, ekonomické teorie, etika

\section{Key words:}

Financial stability, Economic theory, Ethics

\begin{abstract}
Abstrakt
Článek se zabývá finanční stabilitou v podmínkách současného ekonomického systému, se zaměřením na detailnější analýzu České republiky prostř̌ednictvím indikátorů finanční stability, a to vše v kontextu globálního vývoje zasaženého finanční krizí. První a druhá část př́ispěvku podává stručný nástin vývoje ekonomického myšlení až po současnost, snažíce se o co nejreálnější a nejobjektivnější kritické zhodnocení aktuálního ekonomického systému. Praktický příklad analýzy finanční stability bude ukázán na př́íkladu České republiky ve třetí části článku. Prostřednictvím vybraných indikátorů finanční stability bude vyhodnoceno celkové zdraví finančního sektoru za období od roku 2006 do roku 2011, částečně i do roku 2012, s přihlédnutím k ekonomickému vývoji ve světě. I když se prozatím jeví finanční stabilita v České republice jako stabilní, další vývoj bude značně záviset na finanční a ekonomické situaci $\mathrm{v}$ ostatních důležitých státech. Na závěr bude poukázáno na přední význam psychologie v ekonomii a důležitost morálních principů.
\end{abstract}

\begin{abstract}
This article deals with the financial stability under conditions of the current economic system, focusing on more detailed analysis of the Czech Republic by using specific indicators of the financial stability in the context of the global situation affected by the financial crisis. The first and second part of the paper will provide a brief overview of the evolution of economic thought to the present, trying to bring the most realistic and objective critical assessment of the current economic system. A practical example of the financial stability analysis will be shown on the case of the Czech Republic in the third section. Through selected indicators of financial stability, the overall health of the financial sector will be assessed. This will be examined for the period from 2006 to 2011, partly in 2012, taking into consideration the development of global economic situation. Although the overall financial stability in the Czech Republic may seem stable, further development will depend substantially on the financial and economic situation in other important states. In the end, the significance of psychology in the economy and the importance of moral principles will be pointed out.
\end{abstract}

\section{Úvod}

Aktuální finanční krize světu opět připomenula zákonitosti opakujících se hospodářských cyklů a křehkost finanční stability. Díky euforii v období hospodářského boomu se snadno zapomíná na nevyhnutelnost příchodu recese. Aktuální forma kapitalistického systému,

\footnotetext{
${ }^{1}$ Tento př́spěvek byl zpracován v rámci projektu IGS VŠE v Praze F2/5/2011: „Význam finančních trhů pro mezinárodní podnikání v podmínkách globalizované světové ekonomiky“.
} 
charakteristická pro ekonomiky vyspělé západní civilizace, však není dokonalá a ohrožují ji její vlastní systémové chyby. Ekonomika funguje v prostředí nedokonalých trhů, asymetrických informací a egoistického chování. Aplikovaná opatření pro rychlé překonání finanční krize mohou vážnější problémy pouze odložit a uklidnit tím veřejnost a finanční trhy pouze v krátkém období, pro obnovení stability v dlouhém období by však bylo zapotřebí systémového hloubkového řešení.

Proč není snadné obnovit finanční stabilitu od vypuknutí hypoteční krize v roce 2007 ? Vyspělé země se potýkají s mnoha systémovými chybami najednou a odstranění těchto nedostatků bude vyžadovat komplexní léčbu. Pouhé kosmetické úpravy tuto krizi jen dále prodlužují. Odkládání nevyhnutelného nakonec může způsobit, že problémy udeří v daleko větším měřítku.

Pochopit správně přítomnost pomůže znalost minulosti a myšlenkových přístupů, které ovlivňovaly historii a spoluvytvářejí přítomnost. V první kapitole článku se tedy podíváme na stručný nástin vývoje ekonomického myšlení a monetárních teorií - od tradice klasické, přes Chicagskou školu, keynesiánství, Rakouskou školu, školu racionálního myšlení, postkeynesiánství, až po kritické zhodnocení současného ekonomického př́ístupu a analýzu vybraných problémů ohrožujících finanční stabilitu - fungování států, bankovního systému a postupnému upadání etiky a morálky, jež bude zachycena v kapitole druhé.

Praktický příklad analýzy finanční stability bude ukázán na př́íkladu České republiky ve třetí kapitole. Prostřednictvím vybraných indikátorů finanční stability, z kterých vychází Česká národní banka pro vypracování Zprávy o finanční stabilitě (ČNB, 2012), bude vyhodnoceno celkové zdraví finančního sektoru za období od roku 2006 do roku 2011, částečně i do roku 2012, s přihlédnutím k vývoji ekonomické situace ve světě.

Cílem práce bude zanalyzovat finanční stabilitu České republiky Vývoj vybraných indikátorů finanční stability bude přehledně zobrazen $\mathrm{v}$ tabulce a následně stručně posouzen $\mathrm{v}$ dalších komentářích. Analýza uvedených indikátorů finanční stability ukáže, jak finanční krize ovlivnila finanční stabilitu v České republice a jaký pravděpodobný scénář dalšího vývoje, s přihlédnutím k vnějším vlivům globálního prostředí, se Českou národní bankou očekává.

V závěru bude poukázáno na přední význam psychologie v ekonomii a důležitost morálních principů.

\section{Vývoj ekonomického myšlení}

Pro bližší pochopení fungování ekonomického systému a finanční stability je vhodné podívat se do historie na vývoj ekonomického myšlení a monetárních teorií. Pouze se znalostmi historie a teorie lze objektivně sledovat probíhající události a analyzovat očekávané souvislosti. Odlišné názory dávají prostor pro další diskuzi a případně mohou pomoci najít nová vysvětlení. Dosažení společného konsensu však není jednoduché a přední ekonomové zaujímají mnohdy značně rozdílná stanoviska.

Následující přehled čerpá zejména z knih Dějiny ekonomického myšlení (Holman, 2005), Makroekonomie. Pokročilejší analýza. 3. část (Mach, 2002) a diplomové práce Mezinárodní akciové trhy v podmínkách finanční krize (Otýpková, 2009).

Klasičtí myslitelé vyzdvihovali liberalismus založený na svobodné tržní konkurenci, svobodě obchodu a upuštění od státních zásahů do ekonomiky, nebot' jak říkají, neviditelná ruka trhu 
by vždy našla tu správnou rovnováhu v ekonomice. Tato teorie je však postavena na mnoha předpokladech, která jsou však v dnešní praxi nemyslitelná. Otázkou také zůstává, do jaké míry by byla tato rovnováha morální a spravedlivá i v jiných oblastech než ekonomických.

Z pohledu monetárních teorií se nejdříve utvářela tzv. kvantitativní teorie peněz. Ta vysvětluje, že zvýšení peněžní zásoby například na dvojnásobek, za jinak nezměněných podmínek, musí o dvojnásobek zvýšit cenovou hladinu. Nebo-li jinak řečeno, množství peněz určuje cenovou úroveň, přičemž peníze se stávají neutrálními.

Na kvantitativní teorii peněz navázal Milton Friedman s tzv. Neo-Kvantitativní teorií peněz, ve které obhajuje udržování tempa růstu peněžní zásoby nejlépe o tempo růstu HDP. A jelikož se tento nedá předpovědět, doporučuje udržovat stálý růst peněžní zásoby o 3-5\% (Holman, 2005, str. 431). Neutralitu peněz vysvětluje Friedman doplněním, že Phillipsova křivka platí pouze v krátkém období (Kadeřábková, 2003, str. 330): „Substituční vztah mezi inflací a reálným outputem je považován za přechodný. V časovém horizontu několika let se reakce reálného outputu na změnu míry růstu nabídky peněz rozptýlí a jako jediný trvalý efekt zůstane zvýšení míry inflace (neutralita peněz)“.

J. M. Keynes spatřoval př́ičiny hospodářského cyklu ve střídání otimistického a pesimistického očekávání. Státní zásahy do ekonomiky jsou, zejména v době recese, během které vládne investiční pesimismus, nevyhnutelné ke stimulaci poptávky. Vláda by si měla v době ekonomického růstu utvářet přebytky, aby v obdobích ekonomického útlumu mohla stimulovat efektivní poptávku expanzivní politikou. Zásah státu do ekonomiky prostřednictvím expanzivní politiky má pomoct rychleji překonat nepříznivé ekonomické období, protože tímto podpoří a rozhýbe klesající poptávku. Stát se v současné době sice snaží zasahovat do nepříznivého ekonomického vývoje, nicméně na místo Keynesovy doporučené fiskální expanzi provádí opatření restriktivní v důsledku nezdravých veřejných financí z minulých let (viz dále).

V Rakousku se vytvořila další specifická větev ekonomů, zastávající důsledný liberalismus a nesouhlas s deficitním hospodařením státu a s úvěrovou expanzí komerčních bank nekrytou vlastními rezervami, ale zaštítěnou centrální bankou jako „věřitelem poslední instance“.

Rakouští ekonomové Ludwig von Mises a Friedrich A. von Hayek viděli příčiny finanční nestability v monopolu vlády (prostřednictvím centrální banky) na kontrolu množství peněz v ekonomice. Úvěrová expanze komerčních bank (kdy centrální banka zde funguje jako věřitel poslední instance), vyvolá změnu v množství peněz v ekonomice a přechodné snížení úrokové míry. Dle jejich názoru přechodný, uměle vyvolaný pokles úrokové míry podává podnikatelům zkreslený pohled na hodnotu kapitálu a dovolí jim provést „špatné“ investice. Toto si však uvědomí teprve poté, co se úroková míra vrátí na svou přirozenou hodnotu.

Odlišné vysvětlení od liberálních ekonomů rakouské školy nabízí Joseph A. Schumpeter. Dle jeho mínění stř́ídání boomů a recesí vzniká v důsledku nárazových inovačních vln. „Tyto inovace spočívaji ve změnách zpưsobu výroby či dopravy, změnách průmyslové organizace, výrobě nových produkti̊n, otevírání nových trhů nebo objevení nových př́rodních zdrojů.“2 Každá inovační vlna je jedinečná, a proto také každé období expanze a recese je jinak dlouhé a jinak intenzivní. Na začátku každé inovační vlny se projevuje tendence k mylnému

\footnotetext{
${ }^{2}$ (Rees-Mogg, 2008)
} 
očekávání trvalejší prosperity a následné přemrštěné investice realizované i méně schopnými podnikateli se po vyčerpání inovační vlny ukážou být špatnými.

Škola racionálního očekávání formuluje hypotézu: pro odhadnutí budoucnosti se nevychází jen z minulé zkušenosti (adaptivní očekávání), ale také z dnešních informací o pravděpodobném budoucím vývoji. Předpokládá člověka racionálního, který se rozhoduje na základě racionálního uvažování a všechny očekávané rozhodnutí dokáže zpracovat a zahrnout do svých očekávání, čímž se jejich účinky zneutralizují: „Neanticipované změny nabídky peněz mají reálné dopady, anticipované jsou neutrální a reálné dopady nemají.... Chce-li tedy $C B$ použít monetární politiku, aby ovlivnila output, méla by používat jen neočekávané změny nabídky peněz. Je-li např. ekonomika v recesi, musí CB použít překvapivé zvýšení nabídky peněz, aby zvýšila output.“ (Kadeřábková, 2003, str. 338)

Na druhou stranu však také někteří ekonomové připouští, že trvalé dopady peněz na reálné veličiny přetrvají i v případě, že pomine peněžní iluze. I když si investoři uvědomí, že místo zvýšení relativních cen došlo ke zvýšení všeobecné cenové úrovně, může i tak zůstat investiční poptávka dostatečně vysoká. Jestliže již jednou rozjeli investiční projekt za vynaložení jistých počátečních nákladů, mohou se rozhodnout v něm i přesto pokračovat.

Postkeynesiánství se snaží vysvětlovat ekonomii na co nejreálnějších předpokladech, zohledňujících nedokonalou konkurenci, pokročilé finanční instituce, odbory, a jiné. Tento směr není prozatím ještě kompletně ucelen. Utváří se monetární teorie, analyzující opačný transmisní mechanismus, tj. působení od ekonomické aktivity k penězům (tyto peníze lze pojmenovat jako tzv. endogenní peníze $\left.{ }^{3}\right)$. $V$ případě finanční krize si centrální banka nemůže dovolit nechat padnout bankovní systém, a proto musí vždy zajistit potřebnou likviditu, funguje tedy jako půjčovatel (věřitel) poslední instance.

Další specifickou myšlenkou postkeynesiánců je jejich pohled na to, že určující determinantou množství peněz představuje poptávka podnikatelů po úvěrech, vycházející z podnikatelských očekávání o příštím objemu produkce. Základním předpokladem stability a růstu lze považovat příjmy firem $\mathrm{v}$ přítomnosti tak, aby dosahovaly úrovně umožňující plynulé splácení v minulosti přijatých úvěrů. (Minsky, 1982).

Finanční stabilita stojí a padá s důvěrou v ní. Pokud jsou na začátku očekávání v podobě budoucího zhodnocení nadměrně optimistická, následná stagnace či dokonce obrat ve vývoji může vést $\mathrm{k}$ insolventnosti a bankrotům. „Ztráta firem dostát svým př́tomným závazkům (splatným dluhům z minulosti), odstartuje proces poklesu investic, agregátní poptávky, důchodu a zaměstnanosti. V tomto okamžiku vystupuje CB jako věritel poslední instance a dodá do ekonomiky chybějící nutnou likviditu pro plynulost finančních tokủ a pro stabilizaci ekonomiky, což může umožnit i přežití firem, které jsou ekonomicky neefektivní. Touto cestou se může soudobá tržní ekonomika vyhnout velkým depresím, avšak za cenu inflačních tlaků a zhoršováni efektivnosti využívání zdrojů ““

Tuto teorii dále více do hloubky rozšiřuje myšlenka, že příčiny hospodářských výkyvů spočívají v nepředvídatelnosti investičních očekávání (at’ už pesimistických či

\footnotetext{
${ }^{3} \mathrm{Na}$ rozdíl od pojetí endogenních peněz bylo u předchozích teorií pojetí exogenních peněz, kdy vedla kauzalita od peněz k ekonomické aktivitě, např. nárůst peněžní zásoby zvyšuje úroveň ekonomické aktivity, zatímco pokles peněžní zásoby ekonomickou aktivitu snižuje.

${ }^{4}$ Mach, 2002, str. 72
} 
optimistických), která se utváří na základě rozhodování $\mathrm{v}$ podmínkách nejistoty a nepředvídatelných událostí (Shackle, 1990).

A podobných vysvětlení by se dalo najít nespočet. Například Antonio Fatás (Redakce, Patria Online, 2011) na svém blogu vysvětluje citlivost současného finančního systému na náladě účastníků tohoto trhu. Optimismus je přitom rozhodující pro zachování finanční stability, což objasňuje na jednoduché rovnici znázorňující výpočet vládního deficitu, který si může země dovolit pro zvládnutí veřejného dluhu. $\mathrm{V}$ rovnici počítá $\mathrm{s}$ velikostí veřejného dluhu, růstem HDP a výnosem z vládních dluhopisů, přičemž varuje před nebezpečnou kombinací zpomalením růstu HDP a navyšování úroku z vládních dluhopisů, která by nezadržitelně vedla k vyhlášení nesolventnosti země.

\section{Kritika současného systému}

Základem správného fungování ekonomického systému (a to nejen v národním, ale i v globálním měřítku) je udržení finanční stability. „ČNB definuje finanční stabilitu jako situaci, kdy finanční systém plní své funkce bez závažných poruch a nežádoucích důsledkủ pro současný $i$ budoucí vývoj ekonomiky jako celku a zároveñ vykazuje vysokou míru odolnosti vůči šokům. “5 Kritiku současného ekonomického přístupu lze provést z různých úhlů pohledů. V tomto článku se však budeme soustředit na analýzu následujících vybraných problémů ohrožující finanční stabilitu: fungování státu, bankovního systému a postupné upadání etiky a morálky.

\subsection{Fungování státu}

Například v současné době jeden z nejaktuálnějších a nejzásadnějších hrozeb - problém vysokého zadlužení a hrozící insolvence států. V důsledku neexistence jasně stanovených pravidel docházelo $\mathrm{k}$ vládním deficitům a narůstání veřejného dluhu i v tzv. dobrých časech, tj. v době ekonomického růstu, kdy by stát měl pomýšlet také na možnost příchodu zhoršení situace a být náležitě připraven. A když si většina lidí nechtěla zpočátku připustit vznik hypoteční krize a její rozšíření do takových rozměrư ${ }^{6}$ jakých nakonec tato aktuální krize nabrala, stalo se nečekané skutečností a stát na toto nebyl připraven.

Následující graf uceleně představuje pořadí vybraných zemí dle výše veřejného zadlužení v roce 2010 v relativním vyjádření jako procento HDP s vyznačením $60 \%$ hranice, od které se stává již velikost dluhu neakceptovatelná pro udržitelný rozvoj a stabilitu (alespoň z pohledu Evropské Unie). Statistická data jsou čerpány ze stránek Mezinárodního měnového fondu (MMF), i když v porovnání se statistikami Central Intelligency Agency (CIA) a Eurostatu (u států Evropské Unie) dochází v některých případech k markantně rozdílným údajům (např. Japonsko, USA, Rakousko).

\footnotetext{
${ }^{5}$ Portál České národní banky: Finanční stabilita, [online, 16.11.2011], dostupné z WWW: http://www.cnb.cz/cs/financni_stabilita/

${ }^{6}$ Otýpková, M.: Finanční krize a její dopad na akciové trhy. Acta Oeconomica Pragensia 4/2010, Praha, 2010, [online, 16.12.2011], dostupné z WWW: http://www.vse.cz/aop/abstrakt.php3?IDcl=309
} 
Graf č. 1: Veřejný dluh (\% HDP) v roce 2010 a rating Moody's vybraných zemí k 19.12.2011

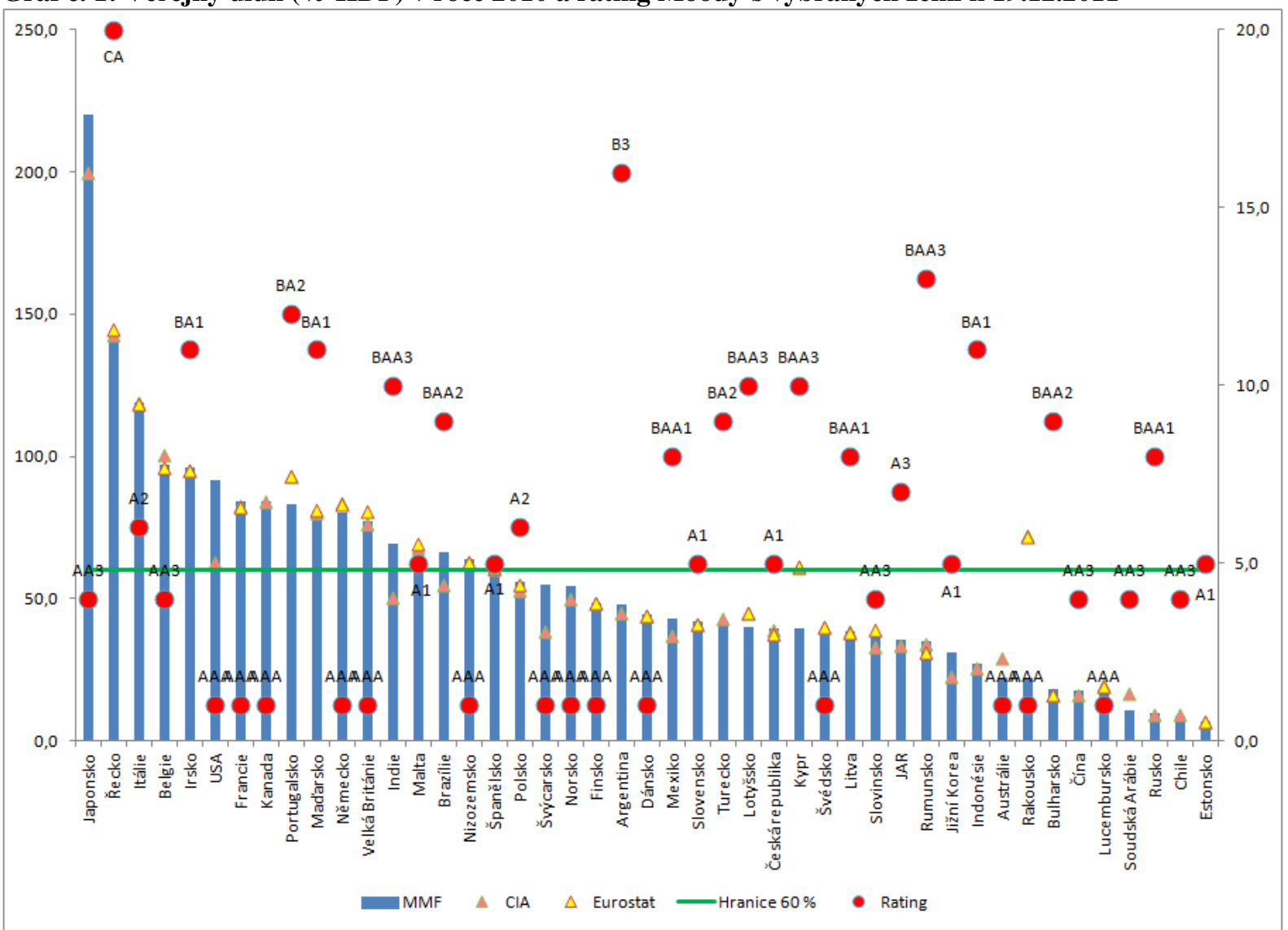

Zdroj: Vlastní graf, hodnoty z portálu Mezinárodního měnového fondu: World Economic Outlook database, portálu Central Intelligency Agency: Country comparison: Public Debt, portálu Eurostat: Euro area and EU27 government deficit at 6,2\% and 6,6\% of GDP respectively a z portálu České národní banky: Srovnávací tabulka ratingového ohodnocení vybraných zemí

Z grafu lze zároveň vyčíst informaci o hodnocení těchto vybraných zemí ratingovými agenturami ${ }^{7}$, které by měly poskytovat nezávislé a transparentní výsledky. S tímto se objevují také další systémové problémy spočívající $\mathrm{v}$ nedostačujících regulačních úpravách o konfliktu zájmu a bezmezné důvěře investorů $v$ neomylnost ratingu. ${ }^{8} \mathrm{I}$ když je velmi snadné, jasné, levné a rychlé rozhodnout se podle ratingu, investoři by ho neměli brát jako určující investiční doporučení, nýbrž by měli brát ohled také na jiné ukazatele a tržní signály.

\subsection{Fungování bankovního systému}

V dnešní době si již nedokážeme představit svět bez bank. Celý tento komplexní bankovní systém nás však drží jako své rukojmí. Bez bank se již v dnešní době neobejdeme. Je však jejich fungování založené na správných základech?

Mnoho bank přežilo aktuální finanční krizi jen díky finanční pomoci státu. (Stiglitz, 2010) Tento morální hazard nelze zanedbat a následující komentáře výstižně zachycují danou skutečnost. „Nemůžete mít na jedné straně socializaci ztrát a na druhé privatizaci zisků, to je podstata kapitalismu.“ (Jonáš, 2009). „The financial instability hypothesis takes banking seriously as a profit-seeking aktivity. Banks seek profits by financing aktivity and bankers.

\footnotetext{
${ }^{7}$ Pro rating zemí bylo náhodně vybráno hodnocení dle agentury Moody’s, které je zobrazeno na stupnici od AAA (nejlepší) po CA (nejhorší), přičemž čítá celkem 20 stupňů. Pro možnost zobrazení v grafu bylo jednotlivý stupňům přiřazeno číslo od $1=$ AAA po $20=$ CA1.

${ }^{8}$ Blíže viz článek autorky o ratingových agenturách (Otýpková, 2011)
} 
Like all entrepreneurs in a capitalist economy, bankers are aware that innovation assures profits. Thus, bankers are Merchant of debt.“ (Minsky, 1992).

Hnací silou růstu jsou finanční inovace a úvěrová expanze. Jak už bylo v první kapitole popsáno, J.A.Schumpeter pojmenovává jako jeden z prvních ekonomů vliv inovací na hospodářské cykly a stabilitu a vysvětluje průběh tzv. inovačních vln, u kterých dochází na počátku k mylnému očekávání trvalejší prosperity, které vyvolají nové investice, jež se po vyprchání iluze ukážou být špatnými. Partnoy (2009) dále poukazuje na to, že s vynalezením nových komplexnějších finančních produktů, však zároveň narůstá pravděpodobnost jejich špatného pochopení a př́lišnou důvěru $\mathrm{v}$ jednoduchou interpretaci. Komplexní přehled literatury k tomuto tématu shrnuje ekonom Tufano (2002) a za hnacím mechanismem finančních inovací vidí rostoucí globalizaci, rychle se měnící podmínky, asymetrické informace, nedokonalý trh a touhu po větším zisku.

Finanční stabilita je také narušena nedokonalým trhem úvěrů (Aghion a Banerjee, 2005, str. 2 nebo Kiyotaki, Moore, 2005). Počátky současné finanční krize vyústily z americké krize na hypotečních trzích, která vypukla $v$ srpnu roku 2007. Z počátku nikdo nevěřil, že situace bude tak dramatická a rozššŕí se na mezinárodní finanční trhy a poté také do světových ekonomik v takovém rozsahu. ${ }^{9}$ Bankroty velkých finančních institucí vyvolaly krizi důvěry doprovázenou snižováním ratingů a kurzy na finančních trzích začaly hromadně klesat. Přeživší banky si mezi sebou navzájem přestaly půjčovat, zvýšily sazby na poskytování úvěru a zpř́ísnily pravidla pro jejich získání. Snížení úvěrové nabídky pak ovlivnilo firmy, které nemohly prostřednictvím bank financovat svůj operativní provoz. Došlo tedy k materiálním i personálním redukcím, snížení výroby a v konečném důsledku k recesi. ${ }^{10}$

Zpráva o finanční stabilitě 2010/2011 vydaná Českou národní bankou hovoří o nadále vysoké míre nejistoty a nepř́liš optimistických očekáváních do budoucnosti. „Systémová rizika naakumulovaná $v$ gloválním finančním systému v predcházejícím období jsou stále natolik silná, že vyžaduji pokračování podpurných hospodárských politik. Jejich předčasné ukončení by mohlo ohrozit křehkou situaci na finančních trzích. Při vysoké míre zadluženosti vlád se veřejnost stále více spoléhá na politiky centrálních bank. Velmi nízké úrokové sazby však zároveň vystavují tvưrce měnové politiky v některých zemích konfliktu mezi cíli cenové stability a finanční stability. “"

Složitou úlohu centrálních bank při volbě mezi cenovou či finanční stabilitou popisuje také Boldea (2010): „Failure in maintainging financial stability can only lead to an inflation growth. “Některá opatření CB můžou vést k posílení cenové stability na úkor celkové finanční stability a naopak. Například úroková sazba, která ovlivňuje spotřebu, úspory a investice. Snížení úrokové sazby podporuje spotřebu na úkor úspor (nízký úrok z vkladů) a investice (nízký úrok z půjčky), což působí kladně na finanční stabilitu, ale cenovou stabilitu to může ohrozit nebezpečí inflace.

\footnotetext{
${ }^{9}$ Blíže o rozsahu současné finanční krize pojednává následující vědecký článek autorky: Finanční krize a její dopad na akciové trhy. (Otýpková, 2010)

${ }^{10}$ Portál http://xbender.wordpress.com: Jak začala současná finanční krize? Ř́jen 2008, [online, 1.3.2009], dostupné z WWW: http://xbender.wordpress.com/2008/10/09/jak-zacala-soucasn-financn-krize/

${ }^{11}$ Portál České národní banky: Zpráva o finanční stabilitě 2010/2011, [online, 16.11.2011], dostupné z WWW: http://www.cnb.cz/miranda2/export/sites/www.cnb.cz/cs/financni_stabilita/zpravy_fs/fs_2010-2011/fs_20102011_shrnuti.pdf
} 


\section{3. Úpadek etiky a morálky}

Podstatu všech těchto výše vyjmenovaných hrozeb je třeba hledat daleko více do hloubky. Nelze řešit každý problém zvlášt' odděleně, je třeba se podívat na společný jmenovatel a nacházet řešení od základu.

Za tento společný jmenovatel lze označit úpadek morálního chování. Tomáš Sedláček ve své knize Ekonomie dobra a zla (2009) zkoumá historické prameny stáré tisíce let a nachází plno výroků s podobným závěrem. Pro př́klad lze uvést následující: „Ekonomický cyklus, jehož vysvětlení je dodnes ekonomům záhadou, se ve Starém zákoně vysvětluje morálně. V dobách, kdy Izrael dodržoval zákon a spravedlnost, neutiskoval vdovy a sirotky a byl poslušen Hospodinových přikázání, národ prosperoval. Vopačném prípadě nastávala hospodárská a společenská krize."

Tomáš Bat’a v roce 1932 charakterizoval Velkou Depresi jako výsledek morálního úpadku: „Mravní bída je př́čina, hospodářský úpadek je následek. (...) Máte pravdu, je třeba překonat krizi důvěry, technickými zásahy, finančními a úvěrovými ji však překonat nelze, důvěra je věc osobni a di̊věru lze obnovit jen mravním hlediskem a osobním př́ikladem."

Bankovní systém vyspělých zemí se velmi vzdálil od morálních principů jako jsou čestnost, svědomitost, solidarita, transparentnost, šlechetnost, pokora, péče o klienta, rozvážnost. Místo toho se zdá, že fungování současné ekonomiky je založeno na maximalizaci zisku pomocí egoismu, polopravd, závisti, vykořist'ování a neuvážlivého riskování.

Dochází k narůstajícímu přerozdělování od chudých k bohatým. Ti, kteří peníze mají, vydělávájí na úrocích. Ti, kteří peníze nemají, musí tyto úroky platit. „Money is going from those who would spend it to those who already had more than they needed." (Stiglitz, 2010, str. 35).

Ačkoli banky a bankéři $\mathrm{v}$ nich pracující mohou být právem obviňováni $\mathrm{z}$ chyb vedoucích $\mathrm{k}$ finanční krizi, je třeba vzít také $\mathrm{v}$ úvahu to, že jim to bylo dovoleno a umožněno nedostatečným nastavením pravidel. (Graafland, 2011) Místo liberalizace finančního trhu a riskantních strategií ženoucích se za větším ziskem vyžadovaným akcionáři by mělo být nastaveno bankovnictví etické zabezpečující nejen hospodářský vývoj a zisk, ale také finanční udržitelnost s maximální podporou transparentnosti financovaných projektů. (Barbu a Boitan, 2009)

\section{Finanční stabilita v České republice}

Provádět analýzu vývoje finanční systému, přispívat k jeho stabilitě a každoročně vydávat Zprávu o finanční stabilitě, je v českém prostředí povinností ČNB. Cílem této kapitoly bude zhodnotit poslední „Zprávu o finanční stabilitě 2011/2012“12, opírající se o konkrétní indikátory finanční stability a o zátěžové testy odolnosti bankovního sektoru jako celku vůči možným nepříznivým šokům v podmínkách alternativních makroekonomických scénářů.

I když je situace na českém finančním trhu stabilizovaná, při hodnocení v globálním měřítku přetrvávají obavy z budoucího ekonomického vývoje v eurozóně a jeho přenesený dopad na finanční trh v České republice.

\footnotetext{
${ }^{12}$ Portál České národní banky: Zpráva o finanční stabilitě 2011/2012, [online, 29.08.2012], dostupné z WWW: http://www.cnb.cz/miranda2/export/sites/www.cnb.cz/cs/financni_stabilita/zpravy_fs/fs_2011-2012/fs_20112012.pdf
} 
Pro zjednodušení, zároveň však se zachováním celkového výsledného vjemu, se v následující tabulce uvádí některé vybrané indikátory finanční stability, které budou následně stručně charakterizovány v kontextu aktuálního dění.

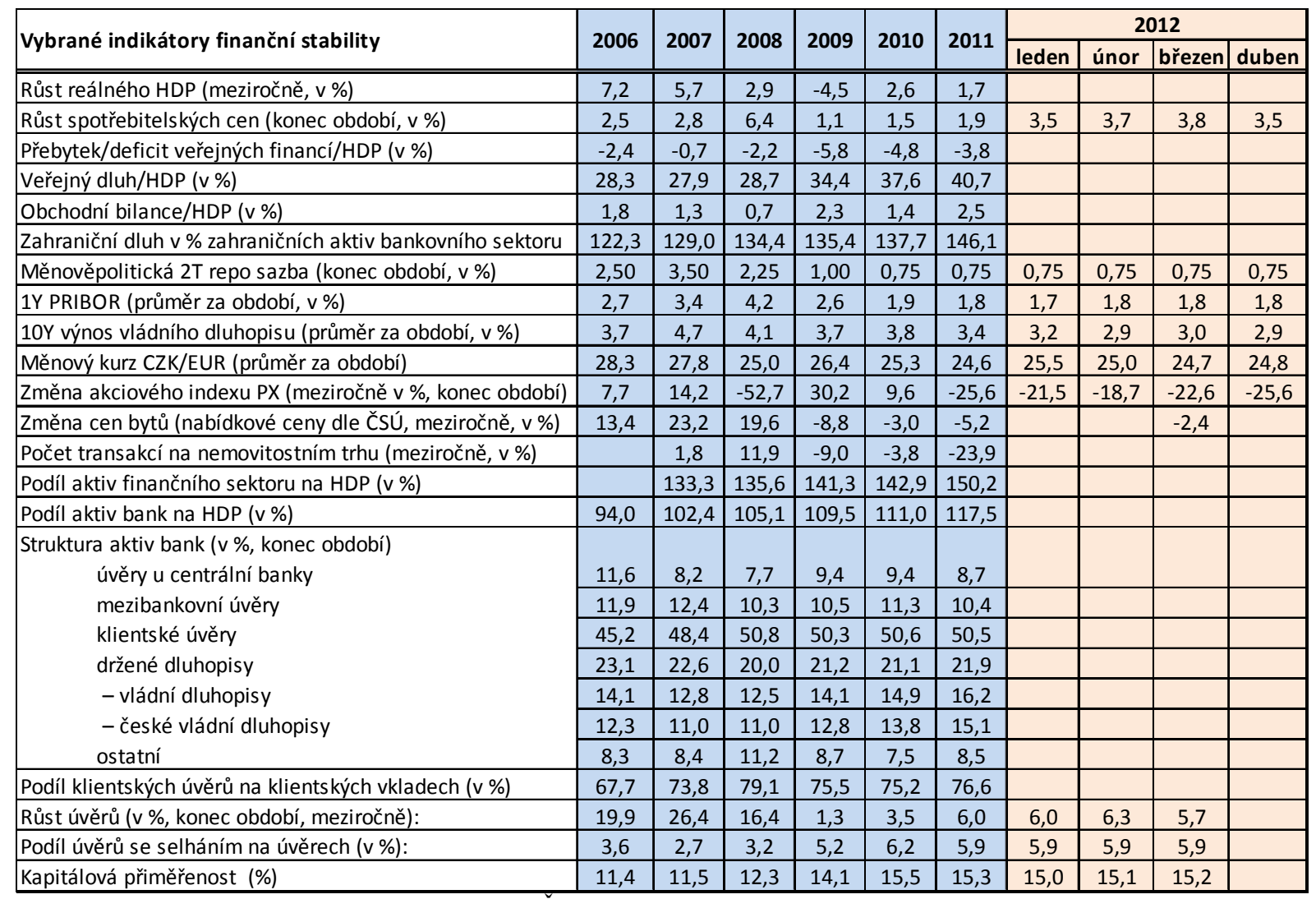

Zdroj: Vlastní graf, hodnoty z portálu České národní banky: Zpráva o finanční stabilitě 2011/2012

Jak lze sledovat z výše uvedené tabulky, současná finanční krize se postupně promítla do všech vybraných indikátorů finanční stability a lze tak jednoznačně deklarovat její významný vliv na finanční stabilitu České republiky. Zatímco se v době hospodářského růstu nedbalo na výrazné snížení veřejného dluhu, po vypuknutí finanční krize a příchodu recese došlo k výraznému deficitu veřejných financí (až téměř k $6 \%$ hranici Maastrichtského kritéria) a dalšímu prohloubení celkového zadlužení.

Nedostatečné rezervy pro období hospodářského útlumu si proto vyžádaly navíc fiskální restrikci, což je přesně v rozporu základního keynesiánského myšlení, kdy by vláda měla v době ekonomického růstu utvářet přebytky, aby v obdobích ekonomického útlumu mohla stimulovat efektivní poptávku expanzivní politikou. Zásah státu do ekonomiky prostřednictvím expanzivní politiky by podle Keynese měla pomoct rychleji překonat neprríznivé ekonomické období, protože se tímto podpoří a rozhýbe klesající poptávka.

Centrální banka díky včasnému vyhodnocení situace a účinné monetární expanzi v podobě velmi uvolněné monetární politiky významně přispívá k zajištění stability finančního prostředí. Z výše uvedené tabulky nelze přehlédnout výrazné snížení úrokových sazeb, které hrálo a stále hraje stěžejní roli pro stabilizaci zamrznutého hypotečního trhu a nedůvěřivým spekulacím na akciovém trhu. V tomto ohledu ČNB zmiňuje nutnost provést zátěžové testy na př́ípadný růst úrokových sazeb, který by mohl ve střednědobém výhledu nastat. 
Doposud provedené zátěžové testy prokázaly vysokou míru odolnosti českého bankovního sektoru jako celku vůči alternativním nepř́íznivým scénářům, a to i dokonce pro krajní scénář „Evropa v depresi“, který testuje stabilitu finančního systému za hypotetických velmi neprríznivých podmínek jako jsou například následující negativní předpoklady: dlouhodobý propad ekonomických aktivit, výrazný propad cen nemovitostí, nárůst úvěrů v selhání, pokles provozních zisků finančních institucí, nepříznivý vývoj na finančních trzích, odpisy pohledávek za zadluženými zeměmi EU, ztráty z expozic domácích bank na zahraniční mateřské společnosti, odliv depozit, zvýšené čerpání úvěrových příslibů či systémové riziko způsobené reakcemi bank ve snaze uzavřít likviditní mezeru.

Kromě své účinné a transparentní politiky se ČNB daří udržovat vysokou míru důvěry veřejnosti a investorů ve stabilitu českého bankovního sektoru. Nezanedbatelný vliv psychologie zde hraje klíčovou roli v posouzení toho, do jaké míry se ještě dá finanční prostředí považovat za stabilní.

\section{Závěr}

Nedokonalost současně fungujícího systému, vedoucí k opakujícím se krizím, si žádá větší zamyšlení se nad jeho nedostatky, odpoutání se od zájmu vlivných skupin a politických rozhodnutí, s cílem nezávisle a objektivně pojmenovat chyby a vymezit možnosti řešení $\mathrm{s}$ alespoň přibližně předem vytyčenými dlouhodobějšími vizemi. Bez zásadní celkové transformace systému bude jen velmi těžké čelit systémovým rizikům, rizikům v bankovním sektoru, enormnímu zadlužení států a hrozbě rozpadu eurozóny, aniž by došlo k další korekci v podobě ještě hlubší ekonomické krize.

Co se týče finanční stability v České republice, na základě uvedení vybraných indikátorů bylo potvrzeno, že současná finanční situace v České republice se jeví jako stabilní. I když lze z hodnot za období od roku 2006 do roku 2011 (v některých případech 2012), sledovat vysokou míru vlivu finanční krize na jednotlivé ukazatele, celkově se dá aktuální situace posoudit jako stabilizovaná. Nicméně vše bude dále podmíněno kontextu vnějšího dění na globálních trzích, zejména v ekonomikách eurozóny.

Díky finanční krizi došlo k vystř́ízlivění a uvědomění si některých rizik, které v dobách ekonomického boomu byly opomenuty a přehlíženy. (Stiglitz, 2010) ČNB, stejně jako další centrální banky, uplatňují politiku monetární expanze s velmi nízkými úrokovými sazbami, což by mělo pomoci k obnovení finanční stability. Na druhou stranu, pokud tato uvolněná měnová politika bude pokračovat př́liš dlouho, investoři budou opět hnáni do rizikovějších investic a vyvolá to další distorzi trhu. (Oppers, 2011)

Západ by měl být sám k sobě mnohem kritičtější, definovat správně nedostatky kapitalistického systému a rychle se adaptovat na stále se měnící podmínky (Patria, 2011). Finanční stabilita je limitovaná nedostatky současného ekonomického systému a žádá si radikální inventuru. Bylo by zapotřebí změnit celkový pohled na svět a vnímání důležitosti morálních principů. Úpadek těchto morálních principů by se dalo nazvat externalitou, selháním trhu, kdy by se stát měl postarat o jeho nápravu a nastavil takové klima, aby se lidé začali chovat více eticky. 


\section{Literatura:}

[1] Aghion, P.; Banerjee, A.: Volatility and growth. Oxford University Press Inc., New York, 2005, ISBN 978-0-19-924861-2

[2] Barbu, T.C. a Boitan, I.A.: The Financial crisis' impact on ethical financial institutions. Annals of the University of Oradea, Economic Science Series, 2009, Vol. 18 Issue 3, p467-473

[3] Bat’a, T.: Úvahy a projevy. Zlín: Univerzita Tomáše Bati: Krajský úřad, 2002, ISBN 807318-103-7 (brož.)

[4] Graafland, J. J.; van de Ven, B. W.: The Credit Crisis and The Moral Responsibility of Professionals in Finance, Journal of Business Ethics, 2011, str. 605-619

[5] Holman, R. a kol.: Dějiny ekonomického myšlení. C. H. Beck, Praha, 3. vyd., 2005, ISBN 80-7179-380-9

[6] Jonáš, O.: Hamižnost je přirozená stejně jako touha, 2009, [online, 22.11.2011], dostupné z WWW: http://www.akciecz.com/news/ondrej-jonas-rozhovor-s-jednim-zarchitektu-toxickych-financnich-produktu/

[7] Kadeřábková, B.: Úvod do makroekonomie. Neoklasický přístup. C. H. Beck, Praha, 2003, ISBN: 80-7179-788-X

[8] Keynes, J. M.: The General Theory of Employment, Interest and Money. Harcourt, Brace and Company, New York, 1936, str. 161-162

[9] Kiyotaki, N., Moore, J.: Credit cycles. Journal of Political Economy, Vol. 105, No. 2, str. 211-248

[10] Mach, M: Makroekonomie II, 1. část, Melandrium, Praha, 1998, ISBN 80-86175-03-0

[11] Mach, M.: Makroekonomie. Pokročilejší analýza. 3. část, Melandrium, Slaný, 1. vyd., 2002, ISBN: 80-86175-22-7

[12] Minsky, H.P.: „Can “it“ happen again?: Esssays on Instability and Finance“. M.E. Sharpe, New York, 1982

[13] Minsky, H.P.: The Financial Instability Hypothesis. The Jerome Levy Economics Institute of Bard College, Working Paper No. 74, květen 1992, str. 1-9

[14] Oppers, S.E. a další: Long-term Investors and Their Asset Allocation: Where are they now? Global Financial Stability Report, 2011

[15] Otýpková, M.: Finanční krize a její dopad na akciové trhy. Acta Oeconomica Pragensia 4/2010, Praha, 2010, [online, 16.12.2011], dostupné z WWW: http://www.vse.cz/aop/abstrakt.php3?IDcl=309

[16] Otýpková, M.: Mezinárodní akciové trhy v podmínkách finanční krize. Diplomová práce, VŠE Praha, 2009

[17] Otýpková, M.: Regulation of credit rating agencies. Konference Česko a Slovensko v Medzinárodnom Obchode a Podnikaní, 2011, str. 277-285

[18] Partnoy, F.: Historical Perspectives on the Financial Crisis: Ivar Kreuger, the Credit Rating Agencies, and Two Theories about the Function, and Dysfuncion, of Markets. San Diego Legal Studies Paper No. 10-009, 2009, str. 431-443

[19] Portál České národní banky: Finanční stabilita, [online, 16.11.2011], dostupné z WWW: http://www.cnb.cz/cs/financni_stabilita/

[20] Portál České národní banky: Srovnávací tabulka ratingového ohodnocení vybraných zemí, [online, 19.12.2011], dostupné z WWW: http://www.cnb.cz/cs/o_cnb/mezinarodni_vztahy/rating/index.html

[21] Portál České národní banky: Zpráva o finanční stabilitě 2010/2011, [online, 16.11.2011], dostupné z WWW: http://www.cnb.cz/miranda2/export/sites/www.cnb.cz/cs/financni_stabilita/zpravy_fs/fs _2010-2011/fs_2010-2011_shrnuti.pdf 
[22] Portál České národní banky: Zpráva o finanční stabilitě 2011/2012, [online, 29.08.2012], dostupné z WWW:

http://www.cnb.cz/miranda2/export/sites/www.cnb.cz/cs/financni_stabilita/zpravy_fs/fs _2011-2012/fs_2011-2012.pdf

[23] Portál Central Intelligency Agency: Country comparison: Public Debt, [online, 27.11.2011], dostupné z WWW: https://www.cia.gov/library/publications/the-worldfactbook/rankorder/2186rank.html

[24] Portál Eurostat: Euro area and EU27 government deficit at 6,2\% and 6,6\% of GDP respectively, October 2011, [online, 27.11.2011], dostupné z WWW: http://epp.eurostat.ec.europa.eu/cache/ITY_PUBLIC/2-21102011-AP/EN/2-21102011AP-EN.PDF

[25] Portál Mezinárodního měnového fondu: World Economic Outlook database, duben 2011, [online, 27.11.2011], dostupné z WWW: www.imf.org/external/pubs/ft/weo/2011/01/weodata/download.aspx

[26] Portál Patria: Evropu zachrání snad jen vlna optimismu, Praha, 2011, [online, 28.11.2011], dostupné z WWW: http://www.patria.cz/zpravodajstvi/1957413/evropuzachrani-snad-jen-vlna-optimismu.html

[27] Portál Patria: Ferguson o kolapsech civilizací a o konci dominance Západu, Praha, 2011, [online, 28.11.2011], dostupné z WWW: http://www.patria.cz/zpravodajstvi/1943271/ferguson-o-kolapsech-civilizaci-a-o-koncidominance-zapadu.html

[28] Portál Thinkmarkets: "In the Long Run We Are All Dead" What Does It Mean? 2010, [online, 18.12.2011], dostupné z WWW:

http://thinkmarkets.wordpress.com/2010/06/28/\%E2\%80\%9Cin-the-long-run-we-areall-dead\%E2\%80\%9D-what-does-it-mean/

[29] Portál http://xbender.wordpress.com: Jak začala současná finanční krize? Říjen 2008, [online, 1.3.2009], dostupné z WWW: http://xbender.wordpress.com/2008/10/09/jakzacala-soucasn-financn-krize/

[30] Rees-Mogg, W.: Business Cycle Theory Explained by Joseph Schumpeter. The Daily Reckoning, 2008, s. 1 [online, 27.2.2009], dostupné z WWW:

http://www.dailyreckoning.com.au/business-cycle-joseph-schumpeter/2008/10/02

[31] Sedláček, T.: Ekonomie dobra a zla. 65. pole, Praha 2009, ISBN: 978-80-903944-3-8

[32] Shackle, G. L. S.: Time, expectations and uncertainty in economics: Selected essays of G. L. S. Shackle, 1990, ISBN 1-85278-362-1

[33] Stiglitz, J.E.: A New Capitalist Order. Global Finance, březen 2010, Vol. 24 Issue 3, str. 33-38

[34] Tufano, P.: Financial Innovation. Harvard Business School, Boston, Massachusetts, The Handbook of the Economics of Finance, 2002

\section{JEL B1, B2, E5, E6, G1, G2, P1}

\section{Ing. Michaela Otýpková}

Kombinované doktorské studium

Katedra mezinárodního obchodu

Fakulta mezinárodních vztahů

Vysoká škola ekonomická v Praze

nám. W. Churchilla 4, 13067 Praha 3

michaela.otypkova@gmail.com 